\title{
Analisis Efektivitas Pembelajaran Daring Pada Mata Kuliah Konsep Dasar IPA Biokimia Mahasiswa Pendidikan Guru Sekolah Dasar
}

\author{
Kartini \\ Dosen Universitas Borneo Tarakan, Tarakan, kalimantan Utara \\ E-mail: kartinipgsd@borneo.ac.id
}

\section{Article Info \\ Article History \\ Received: 2021-01-12 \\ Revised: 2021-02-01}

Published: 2021-02-12

Keywords:

Pembelajaran Daring;

Konsep Dasar IPA;

Biokimia.

\begin{abstract}
The effectiveness of learning is a measure of the success of a learning process between students and students, and / or students and lecturers. The purpose of this study was to determine the effectiveness of the basic concepts of biochemical science courses during online learning. The research method uses a qualitative approach, which has natural characteristics (natural setting) as a direct, descriptive data source, the process is more important than the results.Based on the results of research and analysis of research data, it was found that the results of respondents were that $57 \%$ of student activities tried to keep up with every lesson with maximum and full of concentration, $20 \%$ are able to follow learning well, $15 \%$ are normal in taking lessons, and $15 \%$ are less active and only a requirement for meeting attendance is to fulfill course scores. The discussion method in online learning that gets a dominant place during the implementation of Biochemistry course meetings is $87 \%$ and individual assignments are $80 \%$ of respondents while other methods have an average of $30 \%$ respondent results. For physical conditions, about $90 \%$ of the respondents experienced eye fatigue, $78 \%$ had headaches, and other results were below $30 \%$. In a psychological condition, $90 \%$ of the respondents chose to experience dizziness and boredom, while others were under $40 \%$.
\end{abstract}

\begin{tabular}{l}
\hline Artikel Info \\
\hline Sejarah Artikel \\
Diterima: 2021-01-12 \\
Direvisi: 2021-02-01 \\
Dipublikasi: 2021-02-12
\end{tabular}

Kata kunci:

E-Learnig;

Konsep Dasar IPA;

Biokimia.

\begin{abstract}
Abstrak
Efektivitas pembelajaran merupakan tolak ukur keberhasilan dari sebuah proses
pembelajaran antara mahasiswa dengan mahasiswa, dan atau mahasiswa dengan
Dosen. Tujuan dari penelitian ini untuk mengetahui efektivitas matakuliah konsep
dasar IPA biokimia selama pembelajaran daring. Metode penelitian menggunakan
pendekatan kualitatif, yang mempunyai karakteristik alami (natural setting) sebagai
sumber data langsung, deskriptif, proses lebih dipentingkan dari pada hasil,
Berdasarkan hasil penelitian dan analisis data penelitian, ditemukan hasil responden
yaitu $57 \%$ aktivitas mahasiswa berusaha tetap mengikuti setiap pembelajaran dengan
maksimal dan penuh konsentrasi, $20 \%$ mampu mengikuti pembelajaran dengan baik,
$15 \%$ biasa saja dalam mengikuti pembelajaran, dan $15 \%$ kurang aktif dan hanya
syarat kehadiran pertemuan untuk pemenuhan nilai matakuliah saja. metode diskusi
dalam pembelajaran daring yang mendapatkan tempat dominan selama pelaksanaan
pertemuan matakuliah Biokimia yaitu $87 \%$ dan penugasan individu sebanyak $80 \%$
responden sedangkan metode lainnya rata-rata memiliki hasil responden sebanyak
$30 \%$. Untuk kondisi fisik sekitar $90 \%$ hasil responden mengalami mata kelelahan, $78 \%$
sakit kepala, dan hasil lainnya di bawah $30 \%$ pada kondisi psikis, responden memilih
terbanyak sebesar $90 \%$ mengalami pusing dan bosan, sedangkan lainnya di bawah
40\%.
pembelajaran antara mahasiswa dengan mahasiswa, dan atau mahasiswa dengan Dosen. Tujuan dari penelitian ini untuk mengetahui efektivitas matakuliah konsep sumber data langsung deskriptif, proses lebih dipentingkan dari pada hasil, Berdasarkan hasil penelitian dan analisis data penelitian, ditemukan hasil responden yaitu $57 \%$ aktivitas mahasiswa berusaha tetap mengikuti setiap pembelajaran dengan maksimal dan penuh konsentrasi, $20 \%$ mampu mengikuti pembelajaran dengan baik, $15 \%$ biasa saja dalam mengikuti pembelajaran, dan $15 \%$ kurang aktif dan hanya syarat kehadiran pertemuan untuk pemenuhan nilai matakuliah saja. metode diskusi dalam pembelajaran daring yang mendapatkan tempat dominan selama pelaksanaan pertemuan matakuliah Biokimia yaitu $87 \%$ dan penugasan individu sebanyak $80 \%$ responden sedangkan metode lainnya rata-rata memiliki hasil responden sebanyak 30\%. Untuk kondisi fisik sekitar 90\% hasil responden mengalami mata kelelahan, 78\% sakit kepala, dan hasil lainnya di bawah 30\%. pada kondisi psikis, responden memilih terbanyak sebesar $90 \%$ mengalami pusing dan bosan, sedangkan lainnya di bawah
\end{abstract}

\section{PENDAHULUAN}

Indonesia saat ini tengah dihadapkan tantangan pandemi Covid-19, dimana Pemerintah menghimbau masyarakat Indonesia untuk tetap di rumah saja. Pandemi covid-19 ini tidak hanya mempengaruhi sektor ekonomi dan sosial, namun juga berdampak pada sektor pendidikan, bahwasanya mau tidak mau harus mulai beradaptasi dengan era ini. Dimana kegiatan pembelajaran yang semula dilakukan secara tatap muka beralih menjadi pembelajaran non tatap muka, atau dikenal dengan istilah pembelajaran daring atau sistem E-Leraning. Menurut Isman (2016) pembelajaran daring merupakan pemanfaatan Jaringan internet dalam proses pembelajaran. Daring Dalam kamus Besar Bahasa Indonesia (KBBI) berarti dalam jaringan, yang terhubung melalui jejaring komputer, dan internet. Jadi dapat disimpulkan bahwa pembelajaran daring merupakan suatu upaya dimana mahasiswa dapat melangsungkan pembelajaran tanpaharus tatap muka dengan menggunakan 
jaringan /internet yang telah disediakan oleh Kemendikbud.

Melihat kondisi pandemi covid-19 yang semakin memburuk pemerintah akhirnya harus membuat kebijakan pembelajaran oline atau dalam jaringan (daring) untuk menggantikan pembelajaran konvensional secara tatap muka demi menjamin peserta didik tetap mendapatkan pembelajaran (Herliandry, et.al 2020). Pembelajaran daring dinilai pemerintah sebagai satu-satunya solusi untuk memastikan keberlangsungan proses pembelajaran dari Sekolah Dasar sampai Perguruan Tinggi tetap berjalan (arizona et al., 2020).

Berdasarkan keputusan Bersama Menteri tentang Panduan Penyelenggaraan Pembelajaran Pada tahun Akademik 2020/2021 di masa Pandemic Covid-19 telah mengatur mengenai sistem pembelajaran yang harus dipatuhi oleh semua lembaga pendidikan dari tingkat Pendidikan Dasar hingga Perguruan Tinggi. Dimana pihak Kementrian Pendidikan dan Kebudayaan Pemerintah telah melarang Perguruan Tinggi untuk melaksanakan perkuliahan tatap muka (sadiki et.al. 2020). Bukan tanpa alasan, menutup perguruan tinggi tidak serta merta menghentikan proses belajar, menutup kampus tidak berarti mendeskriditkan pendidikan, menghentikan kuliah bukan berarti tidak peduli dengan masa depan Bangsa, akan tetapi ini semua demi kebiakan bersama agar pandemi Covid-19 ini segera berakhir dan kehidupan kampus kembali normal karena aktivitas belajar merupakan suatu hal yang penting (Titi Rohaeti; Sumliyah, 2020)

Pembelajaran daring merupakasn solusi untuk tetap melaksanakan kegiatan belajar mengajar (Rachmat \& Krisnadi, 2020). Jadi dapat disimpulkan Pelaksanaan pembelajaran berbasis daring sangat dibutuhkan pada saat ini, dikarenakan dapat memberikan dampak positif pada mahasiswa. Walaupun, kenyataanya proses pembelajaran daring masih ditemui beberapa kendala terutama mengenai kondisi setempat dimana jaringan internet yang lemah dan tidak stabil.

a. Efektivitas Pembelajaran

Menurut Rohmawati (2015) efektivitas pembelajaran adalah ukuran keberhasilan dari suatu proses interaksi antar siswa maupun dengan guru dalam situasi edukatif untuk mencapai tujuan pembelajaran. Efektivitas pembelajaran dapat dilihat dari aktivitas mahasiswa selama pembelajaran berlangsung, respon mahasiswa terhadap pembelajaran yang efektif dan efisien perlu adanya hubungan timbal balik antara mahasiswa dan Dosen untuk mencapai suatu tujuan secara bersama, selain itu juga harus disesuaikan dengan kondisi lingkungan Kampus, sarana dan prasarana, serta media pembelajaran yang dibutuhkan untuk membantu tercapainya seluruh aspek pekembangan mahasiswa.

Menurut Supardi (2013) pembelajaran efektif adalah kombinasi yang tersusun meliputi manusiawi, material, fasilitas dan perlengkapan dan prosedur diarahkan untuk mengubah prilaku mahasiswa ke arah yang positif dan lebih baik sesuai dengan potensi dan perbedaan yang dimiliki mahasiswa untuk mencapai tujuan pembelajaran yang telah ditetapkan.

Berdasarkan beberapa pendapat diatas dapat disimpulkan bahwa Efektivitas pembelajaran merupakan tolak ukur keberhasilan dari sebuah proses pembelajaran antara mahasiswa dengan mahasiswa, atau mahasiswa dengan Dosen

b. Pembelajaran Daring (dalam Jaringan)

Menurut Isman (2016) pembelajaran daring merupakan suatu proses pembelajaran yang memanfatakan jaringan internet saat pelaksanaannya, Pembelajaran daring learning sendiri dapat dipahami sebagai pendidikan formal yang diselenggarakan oleh sekolah yang peserta didiknya dan instrukturnya (Dosen) brada di lokasi terpisah sehingga memerlukan sistem telekomunikasi interaktif sebagai media penghubung keduanya dan berbagai sumber daya yang diperlukan didalamnya (Sobron dkk, 2019)

Sayrifudin (2020) pembelajaran daring untuk saat ini dapat menjadi sebuah solusi pembelajaran jarak jauh ketika terjadi bencana alam atau keadaan seperti social distancing. kegiatan diaplikasikannya pembelajaran daring menjadikan kegiatan kegiatan belajar mengajar dalam konteks tatap muka dihentikan sementara, dan diganti dengan sistem pembelajaran daring melalui aplikasi yang sudah tersedia. Pembelajaran daring mengedapankan akan interaksi dan pemberian informasi yang mempermudah peserta didik meningkatkan kualitas belajar. Selain itu, pembelajaran berbasis daring mempermudah satu sama lain meningkatkan kehidupan nyata dalam proses pemeblajaran. Oleh karena itu sangat bermanfaat pembelajaran daring untuk kalangan pendidik dan peserta didik.

Berdasarakan dari beberapa pendapat diatas dapat disimpulkan bahwa pembelajaaran daring merupakan pembelajaran yang dilakukan tanpa harus bertatap muka dimana pembelajaran tersebut hanya membutuhkan jaringan internet yang sudah tersedia.

\section{c. Pembelajaran IPA}

IPA adalah kumpulan ilmu pengetahuan dan fakta, konsep atau prinsi tentang gejala alam yang diperoleh melalui proses ilmiah yang diperoleh melalui proses dan sikap ilmiah. IPA sndiri terdiri dari 3 komponene yaitu sikap ilmiah, proses ilmiah dan prduk ilmiah (Sumarto 2006; Sulistyani, 2008). IPA sebagai proses menyangkut cara kerja untuk memperoleh hasil (produk) dan dikenal sebagai proses ilmiah dan proses ilmiah akan didapat temuan ilmiah. Sains merupakan ilmu empirik yang membahas tentang fakta dan gejala alam maka dalam pembelajarannya harus faktual, artinya tidak hanya secara verbal sebagaimana 
telah terjadi pada berbagai sistem pembelajaran tradisional saat ini.

Proses pembelajaran IPA menekankan pada pemberian pengalaman langsung untuk mengembangakn kompetensi agar menjelajahi dan memahami alam sekitar secara ilmiah (Chan, 201\&). Salah satu ilustrasi yang mampu memberikan informasi penjelasan kepada peserta didik ialah demonstrasi (fatimah, 2017). Jadi dapat disimpulkan dengan kegiatan pembelajaran yang dilaksanakan secara demonstrasi atau pembelajaran langsung dapat mengembangkan rasa ingin tahu dan memecahkan masalah serta membuat suatu keputusan. Berdasarkan hal tersebut yang mendasari penulis untuk mengetahui sejauh mana efektivitas pembelajaran daring di masa pandemi Covid-19 pada mata kuliah konsep dasar IPA Biokimia.

\section{METODE PENELITIAN}

Penelitian yang digunakan adalah penelitian kuantitatif dan kualitatif deskriptif untuk mengetahui gambaran efektivitas pembelajaran daring selama proses pembelajaran berlangsung. Adapun populasi dalam penelitian ini yakni seluruh peserta Lokal A2 angkatan 2019 Jurusan Pendidikan Guru Sekolah Dasar yang mengambil mata kuliah Konsep Dasar IPA Biokimia dengan menggunakan metode daring. Sampel yang menjadi responden penelitian ini sebanyak 37 mahasiswa yang dipilih dengan menggunakan Random sampling dengan mempertimbangkan homogenitas populasi. Adapun instrumen pengumpulan data yaitu menggunakan kuesioner yang berisi jenis pertanyaan tertutup, semi tertutup dan terbuka yang diberikan melalui Google form. Penelitian ini menggunakan pendekatan kualitatif, yang mempunyai karakteristik alami (natural setting) sebagai sumber data langsung, deskriptif, proses lebih dipentingkan dari pada hasil, analisis dalam penelitian kualitatif dilakukan secara analisa induktif serta makna merupakan hal yang esensial (Creswell, 2012). analisis data dalam penelitian ini menggunakan metode analisis deskriptif.

\section{HASIL DAN PEMBAHASAN}

1. Hasil Aktivitas Pembelajaran Daring

Berdasarkan hasil penelitian dan analisis data, ditemukan hasil responden yaitu 57\% aktivitas mahasiswa berusaha tetap mengikuti setiap pembelajaran dengan maksimal termotivasi dalam proses pembelajaran seperti konsentrasi, rasa ingin tahu, mandiri dan antusias, 20\% mampu mengikuti pembelajaran dengan baik, 15\% biasa saja dalam mengikuti pembelajaran, dan 15\% kurang aktif dan hanya syarat kehadiran pertemuan untuk pemenuhan nilai matakuliah saja. Gambar diagram dapat di lihat di bawah ini:

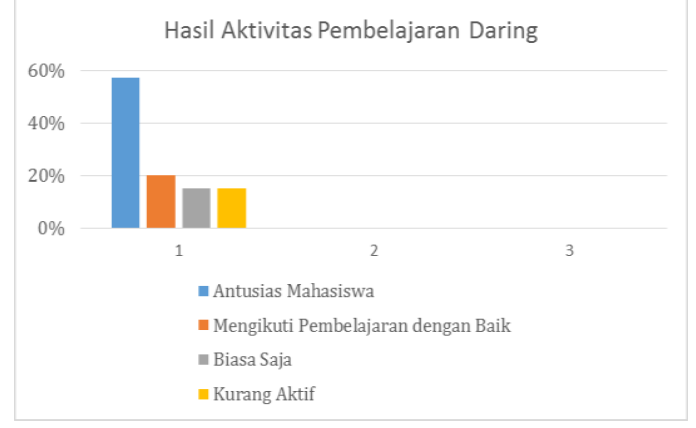

Gambar 1. Hasil Aktivitas Pembelajaran Daring

Dengan demikian, mahasiswa tetap aktif dan termotivasi dalam mengikuti perkuliahan melalui pembelajaran daring. Hal ini sesuai dengan penjelasan Fitriyani (2020) bahwa mahasiswa memiliki motivasi yang sangat tinggi terhadap pembelajaran daring selama masa pandemik Covid-19.

2. Hasil Metode Pembelajaran Daring

Hasil analisis data ditemukan bahwa metode diskusi dalam pembelajaran daring yang mendapatkan tempat dominan selama pelaksanaan pertemuan matakuliah Biokimia yaitu $87 \%$ dan penugasan individu sebanyak 80\% responden sedangkan metode lainnya rata-rata memiliki hasil responden sebanyak 30\%. diagram pelaksanaan metode pembelajaran daring selama pertemuan dapat di lihat pada gambar di bawah ini:

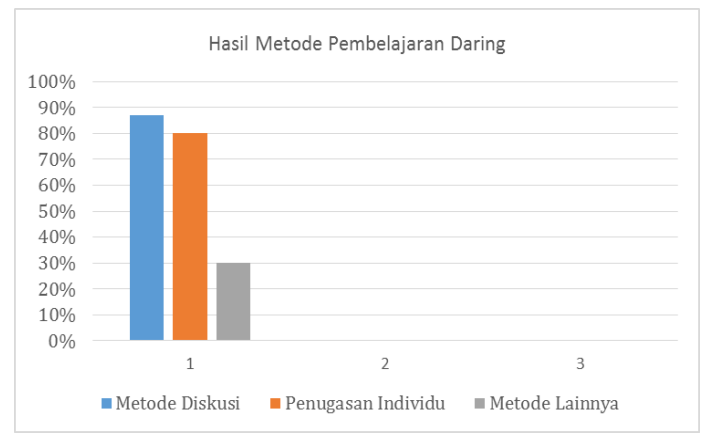

Gambar 2. Hasil Metode Pembelajaran Daring

Hasil tersebut menunjukkan bahwa metode diskusi sangat efektif dilaksanakan pada pembelajaran daring, seperti yang dijelaskan oleh Al Wahid (2020) bahwa sistem perkuliahan model daring dapat mengoptimalkan interaksi antara dosen dan mahasiswa melalui forum diskusi yang terdapat pada platform yang digunakan.

3. Hasil kondisi fisik dan psikis selama pembelajaran daring

Ditemukan berdasarkan hasil jawaban responden terhadap keluhan yang terjadi selama pelaksanaan pembelajaran secara daring. Untuk kondisi fisik sekitar 90\% hasil responden mengalami mata kelelahan, 78\% sakit kepala, dan 
hasil lainnya di bawah 30\%. pada kondisi psikis, responden memilih terbanyak sebesar 90\% mengalami pusing dan bosan, sedangkan lainnya di bawah 40\%. gambar diagram bisa dilihat di bawah ini:

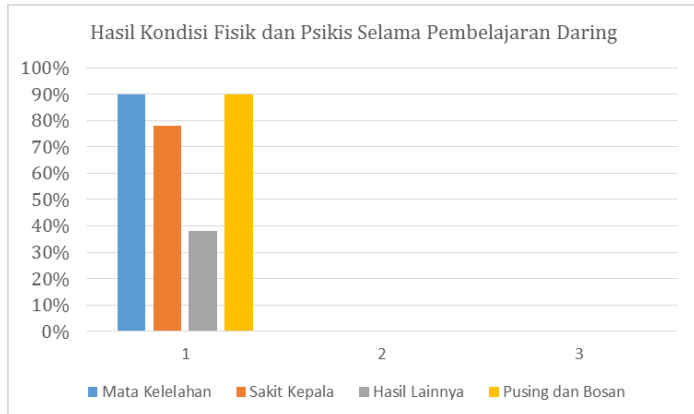

Gambar 3. Hasil Kondisi Fisik dan Psikis Selama Pembelajaran Daring

Kondisi fisik dan psikis mahasiswa menjadi dampak yang kurang baik terhadap pembelajaran daring. Hal ini sesuai dengan pendapat Pawicara (2020) bahwa pembelajaran daring menyebabkan kejenuhan akibat dari faktor eksternal maupun faktor internal seperti kelelahan emosi, kelelahan fisik, kelelahan kognitif, dan kehilangan motivasi.

\section{SIMPULAN DAN SARAN}

\section{A. Simpulan}

Berdasarkan hasil analisis data penelitian dan pembahasan dapat disimpulkan bahwa hasil Aktivitas pembelajaran daring menunjukkan bahwa 57\% mahasiswa berusaha mengikuti pembelajaran dengan maksimal, dan $20 \%$ mengikuti pembelajaran dengan baik, dan 15\% respon biasa saja dan 15\% kurang aktif. Sedangkan untuk hasil metode pembelajaran daring $87 \%$ menggunakan metode diskusi,untuk penugasan individu sebanyak $80 \%$ dan untuk metode lainnya $30 \%$. Sedangkan untuk hasil analisis kondisi fisik dan psikis selama pembelajaran daring berlangsung 78\% koresponden mengalami mata kelelahan hasil lainnya 30\% dan 90\% mengalami pusing dan bosan.

\section{B. Saran}

Hasil penelitian ini diharapkan dapat menjadi bahan evaluasi berbagai pihak dalam menyelenggarakan pembelajaran daring di Perguruan Tinggi, Adapun persiapan yang harus dilakukan Dosen dan Mahasiswa terkait dengan hubungan pedagogik antara dosen dan mahasiswa yaitu ketersediaan sarana dan prasarana seperti media, bahan penggunaan aplikasi dan akses jaringan internet yang terkadang tidak stabil.

\section{DAFTAR RUJUKAN}

Al Wahid, Sucahyo Mas'an, Frendy Aru Fantiro, Dedi Kusnadi. 2020. Persepsi Mahasiswa Dalam Penggunaan Ragam Platform Pembelajaran
Daring. JP2SD (Jurnal Pemikiran dan Pengembangan Sekolah Dasar) Vol. 8, No. 2, September 2020, Hlm. 170-178p-ISSN: 23381140, e-ISSN: 2527-3043 // http://ejournal.umm.ac.id/index.php/jp2sd

Arizona, K., Abidin, Z., \& Rumansyah, R.(2020). Pembelajaran Online Berbasis Proyek Salah Satu Solusii Kegiatan Mengajar di Tengah Pandemi Covid-19. Jurnal Ilmiah Profesi Pendidikan, 5 (1) https://doi.org/10.29303/jipp.v5i1.111, 64-70

Chan, F. 2017. Implementasi Guru Menggunakan Metode Permainan Pada Pelajaran IPA di Sekolah. Jurnal Gentala Pendidikan Dasar, 2(1), 106-123

Fatimah. 2017. Meningkatkan Hasil Belajar Siswa Dalam Pembelajaran IPA dengan Metode Demonstrasi Dikelas V SDN 10 Biau. Jurnal Kreatif Tadulako

Fitriyani, Y., Fauzi, I., \& Sari, M. (2020). Motivasi Belajar Mahasiswa Pada Pembelajaran Daring Selama Pandemik Covid-19. Jurnal Kependidikan: Jurnal Hasil Penelitian dan Kajian Kepustakaan di Bidang Pendidikan, Pengajaran dan Pembelajaran, 6 (2). doi: https://doi.org/10.33394/jk.v6i2.2654 Online, $5(4), 85-96$.

Herliandry, L. D., Nurhasanah, N., Suban, M.E.d, \& Kuswanto, H., (2020).Pembelajaran pada masa Pandemi Covid-19. JTP-Jurnal Teknologi Pendidikan.

https://doi.org/10.21009jtp.v22i1.15286. 65-70

Isman, Mhd.2016. Pembelajaran Media dalam Jaringan (Moda Jaringan). The Progressive and fun Education Seminar ,586

Pawicara, Ruci., Maharani Conilie. 2020. ANALISIS PEMBELAJARAN DARING TERHADAP KEJENUHAN BELAJAR MAHASISWA TADRIS BIOLOGI IAIN JEMBER DI TENGAH PANDEMI COVID-19. ALVEOLI: Jurnal Pendidikan Biologi[Vol. 1, No. 1, Januari-Juni 2020]

Purwanti, E., \& Krisnadi, I. (2020). Implementasi Sistem Perkuliahan Daring Berbasis ICT Dalam Masa Pandemi Wabah Covid-19. Pascasarjana Program Magister Teknik Elektro Universitas Mercu Buana, 1(1), 1-12

Rachmat, A., \& Krisnadi, I. (2020). Analisis Efektifitas Pembelajaran Daring (Online) Untuk siswa SMK Negeri 8 Kota Tangerang Pada saat Pandemi Covid 19 Magister Teknik Elektro Universitas Mercu Buana, 1-7

Rohmawati, Afifatu. 2015, Efekivitas Pembelajaran. Jurnal Pendidikan Usia Dini, 17. 
Syarifudin, Akbitar S. 2020. Implementasi Pembelajaran Daring Untuk Meningkatkan Mutu Pendidikan Sebagai Dampak di Terapkannya Social Distancing. Jurnal Pendidikan Bahasa Indonesia. 31-33

Sobron A.N. B.R.2019.Persespsi Siswa Dalam Studi Pengaruh Daring Learning Terhadap Minat Belajar IPA. Pendidikan Islam dan Multikulturalisme
Sumarto. 2006, Konsep Dasar Berpikir : Pengantar ke Arah Berpikir Ilmiah. Seminar Akademik HUTke 40 FE UPN V Jawa Timur UPN Veteran.

Supardi. Sekolah Efektif. Konsep Dasar Dan Praktiknya. Jakarta : rajawali Pers, 2013 